\title{
研究論文
}

\section{糸染め染色排水の処理プロセスの 性能評価々対策に関する研究}

杉本 太龶礒野 禎三*

\section{要旨}

糸染め染色排水の処理プロセスの処理性能を調べた結果，1日あたりの除去された溶解性の COD 量は 平均して凝集処理工程で約 $50 \%$, 活性污泥処理工程で約 $70 \%$ 除去された。一方, 非超過確率の指標を用い て, 当プラントの処理能力を調べた結果, 溶解性の COD, SS およびろ過液の透視度の各水質項目は, それ ぞれ対数正規分布を示し，年間を通じた水質変動のバラツキに多少偏りはあるが，効率的に処理されてい ることがわかった。

また, 染色排水の模擬排水を用いて, 凝集沈殿処理における COD 成分の処理効率を調べた結果, 界面活 性剂や䣷酸などは，この工程ではほとんど処理されなかった。 キーワード：染色排水，凝集沈殿法，活性污泥法，模擬排水

\section{1. 緒 言}

兵庫県西脇市，多可郡をはじめとする播州織産地 は, 綿, レーヨン等の素材を主体とした系染め染色 産地として形成されている。当産地から排出される 染色排水は, 反応染料を用いて浸染法による染色を 行う性格から, 排水成分には染料や硫酸ナトリウム, 炭酸ナトリウムなどの無機成分, 界面活性剂, 油剂 などの助剤が含まれ, COD が高く, 着色のある処理 困難な排水である. 実際に染色排水の処理に利用さ れている方法としては, 硫酸鉄（II）を凝集剤に用 いた凝集沈殿と活性污泥法を併用した方法が採られ ており ${ }^{1,2)}$, COD 除去を目的とした処理が中心とし てなされている。

近年, 繊維製品の多品種化, 小ロット化，またそ れに伴って使用される繊維薬剤も多種多様化 ${ }^{3)} し て$ おり, その処理も困難なものが多くなっている.こ のため排水の水質や水量変動により基準値をクリア できない場合もあり，その処理の対応に追われてい るのが現状である ${ }^{4)}$.

そこで, 本研究では, 現状の染色排水の処理が行
われている処理プラント（K処理場）の原排水，凝 集沈殿処理水および活性污泥処理水の水質測定を 1 年間にわたって月に 1 回の頻度で行い, 各工程にお ける処理能力の考察を試みた。 また, 特に凝集沈殿 処理工程における処理効率については, 染色排水の 模擬排水を用いて，成分変化によるCOD 除去率へ の影響ならびに問題点, 対策についても検討を試みた。

\section{2. 実験}

\section{1 染色排水の実処理場での調査}

染色加工後の実排水の処理状況の調査において は, 西脇市内の $\mathrm{K}$ 処理場を対象に行った。この処理 場の原排水は, 以下の系染め染色工程（綿，レーヨ ンなどの反応染色）から排出された混合液である.

原糸 $\rightarrow$ 精錬・漂白 $\rightarrow$ 染色 $\rightarrow$ 酸洗い・水洗 $\rightarrow$

$$
\text { ーソーピング処理 } \rightarrow \text { オイリング処理 }
$$

$\mathrm{K}$ 処理場での処理フローと調査での採水箇所を図 - 1 に示す. K処理場では, 流入排水量が約 $2200 \mathrm{~m}^{3} /$ 日であり，凝集沈殿で凝集剂の添加量1200～1500 $\mathrm{mg} / \ell\left(\mathrm{FeSO}_{4} \cdot 7 \mathrm{H}_{2} \mathrm{O}\right.$ として), 反応時間15分 (急速攪 
西脇市内染色工場 6社より流入

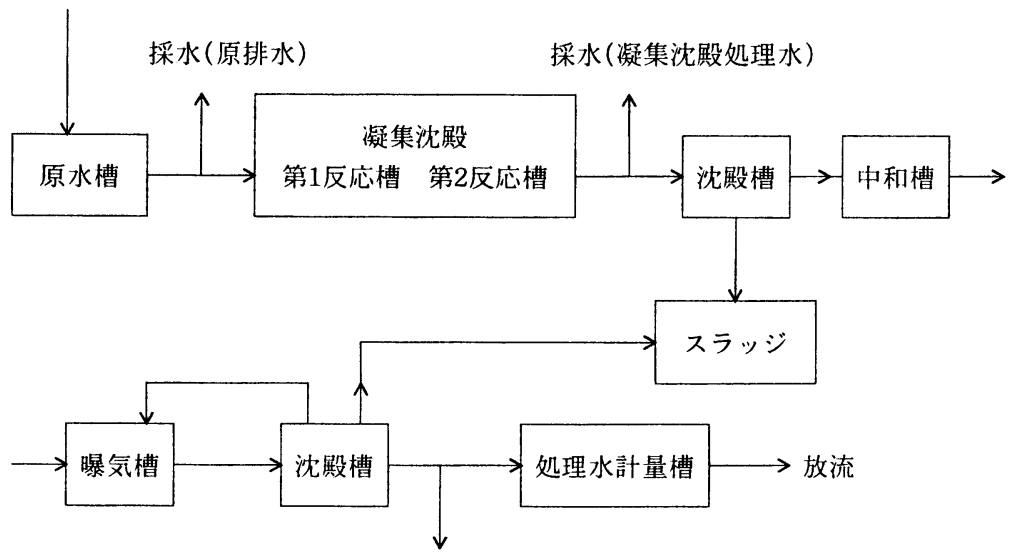

挥：30 rpm, 7.5 分, 緩速攪挥： $15 \mathrm{rpm}, 7.5$ 分）お よび凝集沈殿槽滞留時間2.1時間の処理がなされそ の後に活性污泥処理 (エアレーション8.3時間, 曝気 槽内 MLSS 濃度約 $3100 \mathrm{mg} / \ell$ ）が行われている.

水質測定は，原排水ならびに各処理工程後の処理 水の溶解性 $\mathrm{COD}_{\mathrm{Mn}}$ 濃度（No.5Cのろ紙によるろ 液), $\mathrm{pH}$, 透視度および SS 濃度を測定した。また, 透視度は SS 成分に起因する影響を抑えるため，SS 成分をろ別してろ液を測定した。活性污泥処理水は 最終沈殿槽から放流する際に採水したもので，この 場合の SS は沈殿上澄みの懸濁成分濃度である，各 水質項目の測定法は，JIS K01025)を基に行った。

\section{2 凝集沈殿処理工程における処理効率に関する 実験}

まず, COD 濃度の異なる染色排水 $100 \mathrm{~m} \ell$ に硫酸鉄 （II）を0 2000 $\mathrm{mg} \mathrm{FeSO} \cdot 7 \mathrm{H}_{2} \mathrm{O} / \ell$ 範囲の種々の 濃度で添加して $\mathrm{pH}$ を11亿調節し, 凝集処理(急速攪 汼：120 rpm, 3 分, 緩速攪汼： $60 \mathrm{rpm}, 10$ 分)を行 った後，沈殿物をNo.5Cのろ紙でろ別してろ液の COD を測定し, COD 除去率を算出した.

次に, 排水成分によって COD 除去の難易がある と思われるので，染色の模擬排水を用いて排水の成 分によるCOD 除去率の影響について検討した。模 擬排水は，一般的な反応染色のパターンょり，表 1 に示す組成で調製し，水洗水を考慮してさらに5 倍 および10倍に希釈して用いた。分析操作は, 模擬排 水 $100 \mathrm{~m} \ell$ に凝集剤の硫酸鉄（II）を所定量（1600 mg
$\mathrm{FeSO}_{4} \cdot 7 \mathrm{H}_{2} \mathrm{O} / \ell$ ) 添加し, $\mathrm{pH}$ を0.5N の $\mathrm{NaOH}$ で約 11 に調節後, 急速䚌挥 $120 \mathrm{rpm}, 3$ 分, 緩速攪拌 60 $\mathrm{rpm}, 10$ 分の条件で攪挥を行い，生成した沈殿物を

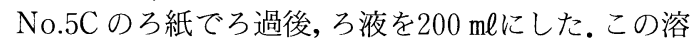
液を検液として COD 濃度を測定した。さらに, 各薬 凨についても同様にして凝集沈殿処理を行い, COD の除去率を測定した.

\section{表 1 模擬排水の組成}

\section{（精錬 - 漂白）}

\begin{tabular}{|c|c|}
\hline 過酸化水素水 $(30 \%)$ & $: 5.0 \mathrm{~g} / \ell$ \\
\hline 水酸化ナトリウム & $: 1.0$ \\
\hline 界面活性㨈（ノニオン）ノイゲン HC* & $: 2.0$ \\
\hline ポリカルボン酸系 ネオレート PLC-2 & $: 2.0$ \\
\hline \multicolumn{2}{|l|}{ (染色 $)$} \\
\hline C. I. Reactive Blue 221 & $: 1.0$ \\
\hline C. I. Reactive Yellow 145 & $: 1.0$ \\
\hline C. I. Reactive Red 223 & $: 1.0$ \\
\hline 無水硫酸ナトリウム & $: 50.0$ \\
\hline 無水炭酸ナトリウム & $: 20.0$ \\
\hline \multicolumn{2}{|l|}{ (酸洗い) } \\
\hline 酢酸（90\%） & $: 3.0$ \\
\hline \multicolumn{2}{|l|}{ (ソーピング処理) } \\
\hline 界面活性剤(ノニオン) ノイゲン HC & $: 1.0$ \\
\hline 無水炭酸ナトリウム & $: 1.0$ \\
\hline \multicolumn{2}{|l|}{ (オイリング処理) } \\
\hline パラフィンワックス系 リポオイル NT-12** & $: 5.0$ \\
\hline
\end{tabular}


表 2 染色排水の水質分析結果

\begin{tabular}{|c|c|c|c|c|c|c|c|c|c|c|c|c|c|c|c|}
\hline 月/日 & & ${ }^{97} 4 / 15$ & $5 / 11$ & $6 / 18$ & $7 / 21$ & $8 / 25$ & $9 / 20$ & $10 / 18$ & $11 / 18$ & $12 / 24$ & $981 / 19$ & $2 / 17$ & $3 / 16$ & Av. & $\sigma_{n-1}$ \\
\hline \multirow{4}{*}{ 原 排 水 } & CODs $(\mathrm{mg} / \ell)$ & 301 & 306 & 302 & 271 & 323 & 348 & 413 & 330 & 371 & 308 & 344 & 471 & 341 & 55.5 \\
\hline & $\mathrm{SS} \quad(\mathrm{mg} / \mathrm{l})$ & 43.9 & 45.8 & 42.6 & 66.2 & 20.0 & 55.0 & 46.7 & 27.6 & 20.9 & 29.6 & 69.0 & 117.6 & 48.7 & 26.9 \\
\hline & $\mathrm{pH}$ & 10.4 & 10.3 & 10.3 & 10.3 & 10.5 & 10.6 & 10.5 & 10.9 & 11.8 & 10.4 & 10.4 & 10.5 & 10.5 & 0.4 \\
\hline & 透視度* (cm) & 3.2 & 3.3 & 2.8 & 3.7 & 3.2 & 2.5 & 2.4 & 3.3 & 2.5 & 3.1 & 2.2 & 1.8 & 2.8 & 0.5 \\
\hline \multirow{3}{*}{$\begin{array}{l}\text { 凝集沈殿 } \\
\text { 処理 水 }\end{array}$} & CODs $(\mathrm{mg} / \ell)$ & 156 & 143 & 165 & 177 & 158 & 181 & 215 & 179 & 199 & 143 & 163 & 207 & 174 & 23.8 \\
\hline & $\mathrm{pH}$ & 9.6 & 8.5 & 9.3 & 9.4 & 9.5 & 9.8 & 9.6 & 9.9 & 10.8 & 9.6 & 9.4 & 9.7 & 9.6 & 0.5 \\
\hline & 透視度* (cm) & 20.8 & 16.5 & 23.5 & 21.5 & 16.0 & 15.7 & 14.5 & 16.6 & 10.4 & 11.6 & 19.2 & 13.4 & 16.6 & 4.0 \\
\hline \multirow{4}{*}{$\begin{array}{l}\text { 活性污泥 } \\
\text { 処 理 水 } \\
\text { (放流水) }\end{array}$} & CODs $(\mathrm{mg} / \ell)$ & 54.8 & 52.6 & 57.6 & 53.2 & 58.4 & 55.4 & 61.2 & 47.8 & 66.8 & 50.0 & 69.4 & 69.8 & 58.1 & 7.4 \\
\hline & $\mathrm{SS} \quad(\mathrm{mg} / \ell)$ & 18.4 & 23.9 & 29.8 & 53.3 & 5.3 & 25.0 & 10.0 & 5.0 & 12.4 & 5.2 & 23.5 & 12.6 & 18.7 & 13.9 \\
\hline & $\mathrm{pH}$ & 8.1 & 8.4 & 8.3 & 8.6 & 8.4 & 8.5 & 8.3 & 8.5 & 8.9 & 8.2 & 8.3 & 8.3 & 8.4 & 0.2 \\
\hline & 透視度 ${ }^{*}(\mathrm{~cm})$ & 26.3 & 22.2 & 20.0 & 16.6 & 20.4 & 14.6 & 19.6 & 22.3 & 13.8 & 24.0 & 10.8 & 15.6 & 18.9 & 4.6 \\
\hline
\end{tabular}

Av. : 平均値, $\sigma_{\mathrm{n}-1}$ : 標準偏差, CODs : 溶解性の COD 濃度 $*$ : 原排水および各処理工程の処理水のろ過水の值

\section{3. 結果と考察}

\section{1 排水処理プラントの処理性能}

染色排水処理の 1 年間の水質結果を表 2 に示す. 原排水の $\mathrm{pH}$ は，年間を通じて大きな変動は見ら れないが, 溶解性の COD や SS 濃度は, その変動が 大きい.これらは，各企業における染料，助剤の使 用量や扱っている素材の違いから見られる季節的な 変化によるものと思われる。1日あたりの溶解性 COD の負荷量は, 原排水で $750 \mathrm{~kg} /$ 日, 凝集沈殿処理 水で383 kg/日, 活性污泥処理水で $128 \mathrm{~kg}$ /日であり, 各工程での 1 日あたりの COD 処理量は，凝集処理 工程で約 $50 \%$ ，そして活性污泥処理工程で残りの約 70\%が除去されていることがわかった。なお，この ような処理は，流入する高負荷排水の時間的な水質 変動および水量変動が問題であり，それらの対応が 要求される.

透視度は, 原排水の場合は, 年間を通して約 $2 \sim 4$ $\mathrm{cm}$ の範囲にあり, 表 2 からもわかるように，凝集処 理工程でかなり改善されている。しかし，活性污泥 処理後の透視度は，凝集処理に比べて大きな変化は なく，放流水は逆に凝集処理後の值に比べ悪化して いる場合もある。これらは染料の復色などによるも のと思われる。

また,この処理工程における溶解性の COD, SS お よびろ過液の透視度の非超過確率を調べた。この値 は，それぞれの水質項目の処理効率を知るための指 標であり，一般に水質母集団の多くは，正規分布ま たは対数正規分布のどちらかに従い，代表值と非超
過確率とを対応させて，確率紙または対数確率紙に プロットすると直線関係が得られる。

そこで，それぞれの水質結果の非超過確率を求め た結果，図一 $2 \sim 4$ に示されるように対数正規分布 を示すことがわかり，また，年間を通じた水質変動 のバラツキに多少偏りがあるものの，排水は効率的 に処理されていることがわかった.つまり, COD 濃 度に抢いて図一2より99\%の確率の場合でも，放流

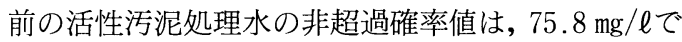
あり,当処理施設の $\mathrm{COD}$ の排出基準値である

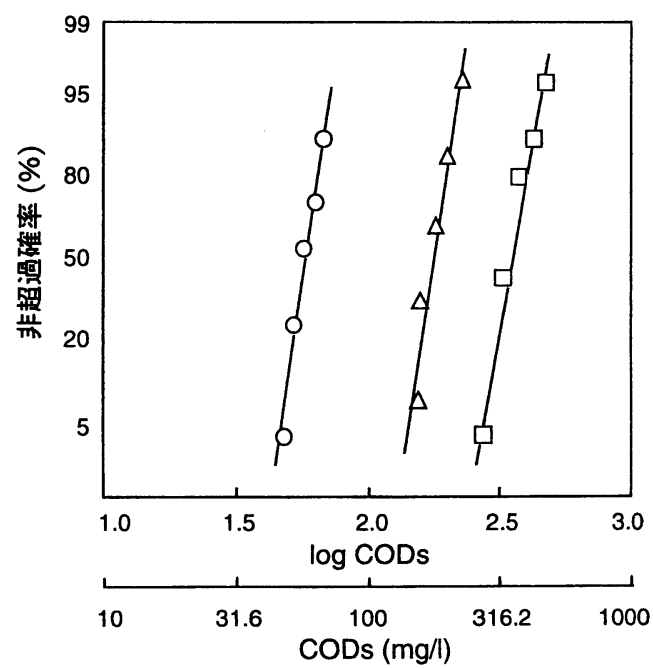

図一2 原排水および各処理水の溶解性 COD の 非超過確率プロット

$\square$ : 原排水 $\triangle$ : 凝集沈澱処理水 $\bigcirc$ : 活性污泥処理水 


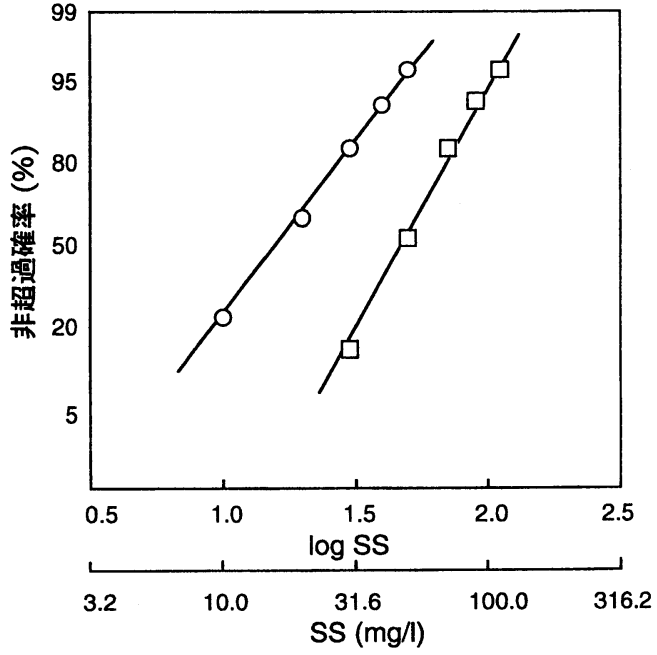

\section{図一 3 原排水および活性污泥処理水の SS の 非超過確率プロット \\ $\square$ : 原排水 $\bigcirc$ : 活性污泥処理水}

80〜 $100 \mathrm{mg} / \ell$ に対して低い值を示している.また, SS についても同様に, 図一 3 より 99\%の確率の場合で も非超過確率值は, 放流前の活性污泥処理水で72.4 $\mathrm{mg} / \ell$ であり，SS の排出規制值の $70 \sim 90 \mathrm{mg} / \ell$ に対し て規制範囲内にあり，十分な処理能力を持ったプラ ントである.なお, ろ過水の透視度については, 図 - 4 上り $80 \%$ の確率においても, 活性污泥処理水の 非超過確率值は $20 \mathrm{~cm}$ 以下であり, SS に起因する以外 の着色成分は, 現状でも残存しており, その向上は あまり期待できないことが示されている.

次に各項目の相関について, 実数值の相関よりも

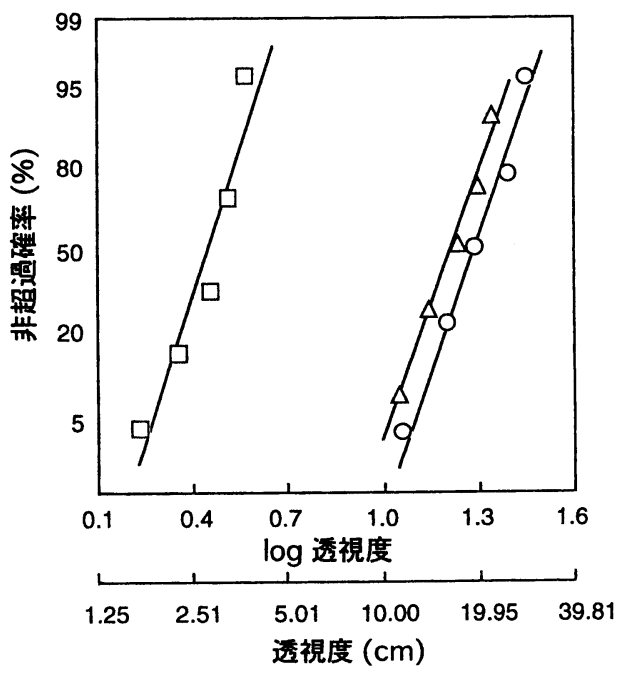

図一４原排水および各処理水の透視度の非超過確 率プロット

$\square$ : 原排水 $\triangle$ : 凝集沈澱処理水 $\bigcirc$ : 活性污泥処理水

対数値の間の相関係数の值の方が大きかったので, 各測定結果の対数值の相関関係を表 3 に示す．表 3 は各工程での COD, pH, SS および透視度の各々 2 項目間の関係を示している.

まず, COD と透視度の関係において, 表 3 より原 排水の COD 濃度と透視度ならびに活性污泥処理水 の COD と透視度にはそれぞれー0.880と-0.724と 高い相関関係があり，同一の排水および処理水間に おいて, COD 值の高低により透視度の良否の目安に なることがわかる。一方, 凝集沈殿処理水の場合, 処理後の排水は全体的に緑色を帯びており，鉄 (II)

表 3 染色排水および処理水の各水質測定値（対数值）間の相関関係

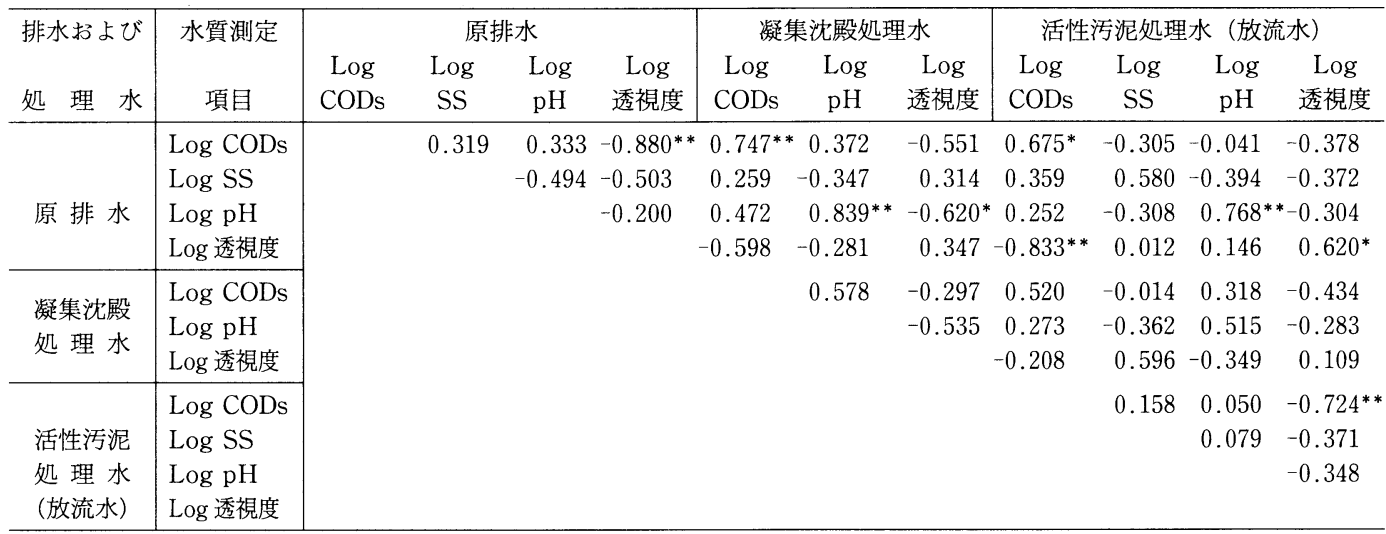

有意水準 : $\mathrm{p}=0.05(*) \mathrm{p}=0.01(* *), \mathrm{CODs}$ : 溶解性の COD 濃度, 透視度 : 原排水および各処理工程の処理水のろ過水 の值 
による還元䨌囲気の影響，または色相のズレからそ れらの相関值は一0.297と低かった.

原排水間，原排水と凝集沈殿処理水および活性污 泥処理水, 活性污泥処理水間の SS 濃度と透視度の 関係に扔いて，その相関係数は，それぞれー0.503，+ $0.314,-0.372,-0.371$ と低い結果となった.このよ うに両者の相関值が低いのは，透視度はろ過水を対 象に測定したものであり，未反応の着色成分であり COD 成分である成分の変動による影響が大きいた めと考えられる。しかし，SS成分を除去しない場合 の通常の $\mathrm{JIS}^{5}$ による測定の場合の透視度は, 年平均 で原排水 $2.3 \mathrm{~cm}$, 凝集沈殿処理水 $4.0 \mathrm{~cm}$, 活性污泥処 理水 $11.1 \mathrm{~cm}$ と過したものよりかなり悪かった。し たがって, COD 除去に加えて,SS 除去を合わせた着 色污染対策が重要な課題になる。

\section{2 凝集沈殿処理工程における処理効率について}

\section{2 .1 実排水を用いた COD 除去率におよぼす初 期 COD 濃度の影響}

3.1 では実際の処理施設の排水の処理効率につい て検討を行った．本節では特に凝集沈殿処理につい て取り上げ，原排水の COD の除去率におよぼす硫 酸鉄（II）凝集剤の添加量の影響について検討し, その処理効果を調べた。

凝集沈殿後のろ液の COD 除去率におよぼす硫酸 鉄 (II) の添加量の影響を図一 5 に示す。硫酸鉄 (II) の添加量の増加とともに COD の除去率は増加する が, 凝集剤を一定以上過㮃に加えても，初期の COD 濃度に関係なくCOD 除去率は余り変化せず，50\% 程度しか除去されないことがわかった。また，COD 除去率の一定值に達するのに必要な凝集剂の添加量 は，初期の COD 濃度が高くなるにしたがって多く なっている。したがって，COD の負荷が大きくなる 場合，スラッジの生成量は増加するが，添加する凝 集剤を増加させる必要がある。

\section{2 .2 染色工程における模擬排水の COD 除去率 の影響}

凝集処理による COD 除去率の影響について検討 した結果を表 4 に示す．各工程の排水において，精 錬・漂白工程では 50 ～60\%程度，オイリング工程で は45〜 50\%が除去されているものの，酸洗いやソー ピング工程の排水では，ほとんど COD 成分の除去 がされていないことが明らかにされている。

\section{2 .3 染料および染色助剤の COD 除去率の影響}

各薬剤の凝集沈殿処理による COD の除去率の影

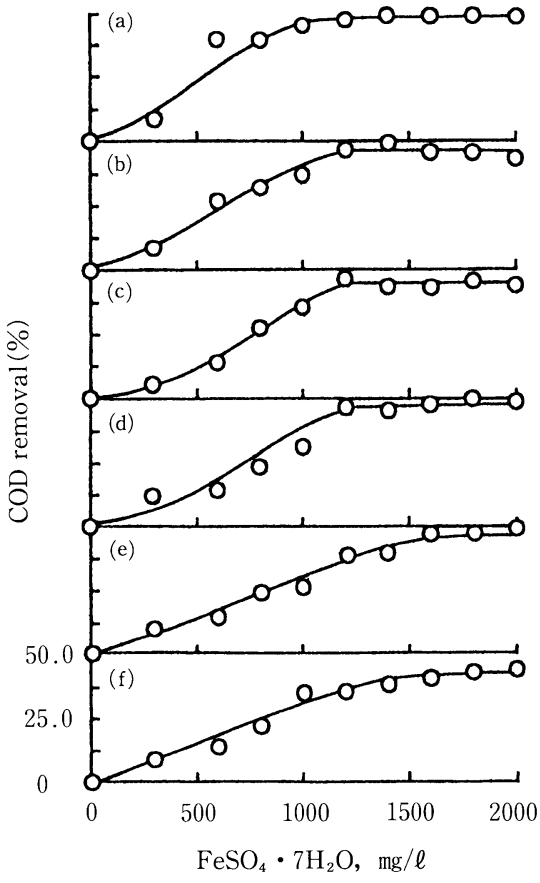

図一 5 COD 除去率におよぼす硫酸鉄（II）凝集剤の 添加量の影響

$\mathrm{pH} 11 ， \mathrm{COD}$ の初期濃度 : (a) $59.2 \mathrm{mg} / \ell$ ，(b) $108.8 \mathrm{mg} / \ell$, (c) $218.0 \mathrm{mg} / \ell$, (d) $306.0 \mathrm{mg} / \ell$, (e) $428.0 \mathrm{mg} / \ell$, (f) $500.0 \mathrm{mg} / \ell$

表 4 各工程における模擬排水の COD 除去率

\begin{tabular}{|c|c|c|c|c|}
\hline \multirow{2}{*}{ 工 程 } & & \multicolumn{2}{|c|}{ 凝集沈殿処理（mg/l） } & \multirow{2}{*}{$\begin{array}{c}\text { COD 除去率 } \\
(\%)\end{array}$} \\
\hline & & 処理前 & 処理後 & \\
\hline \multirow[t]{2}{*}{ 精錬・漂白 } & A & 153.6 & 68.8 & 55.2 \\
\hline & $B$ & 304.8 & 119.6 & 60.8 \\
\hline \multirow[t]{2}{*}{ 染 色 } & A & 36.4 & 28.2 & 22.5 \\
\hline & B & 73.6 & 57.6 & 21.7 \\
\hline \multirow[t]{2}{*}{ 酸洗い } & A & 22.0 & 22.4 & -1.8 \\
\hline & B & 45.2 & 44.8 & 1.3 \\
\hline \multirow[t]{2}{*}{ ソーピング } & A & 23.4 & 23.6 & -0.9 \\
\hline & B & 49.6 & 48.8 & 1.6 \\
\hline \multirow[t]{2}{*}{ オイリング } & A & 70.6 & 35.4 & 49.9 \\
\hline & B & 132.0 & 71.8 & 45.6 \\
\hline 全工程の & A & 332.5 & 175.7 & 47.2 \\
\hline 混合排水 & B & 656.9 & 369.3 & 43.8 \\
\hline
\end{tabular}

$\mathrm{A}$ ：模擬排水の 10 倍希釈 $\mathrm{B}$ ：模擬排水の 5 倍希釈 $\mathrm{pH}: 11, \mathrm{FeSO}_{4} \cdot 7 \mathrm{H}_{2} \mathrm{O}: 1600 \mathrm{mg} / \ell$

響を表 5 に示す。過酸化水素水は鉄（II）による還 元により COD 值は低下するものの，非イオン界面 活性剤（ノイゲンH C ）や酶酸などは，ほとんど処 理されていないことがわかった。美坂的は染色排水 
表 5 染料および染色助剤の COD 除去率

\begin{tabular}{|c|c|c|c|c|}
\hline \multirow[t]{2}{*}{ 薬 剤 } & \multirow{2}{*}{$\begin{array}{l}\text { 濃 度 } \\
(\mathrm{g} / \ell)\end{array}$} & \multicolumn{2}{|c|}{ 凝集沈殿処理 $(\mathrm{mg} / \mathrm{l})$} & \multirow{2}{*}{$\begin{array}{c}\text { COD 除去率 } \\
(\%)\end{array}$} \\
\hline & & 処理前 & 処理後 & \\
\hline \multirow{2}{*}{$\begin{array}{c}\text { 過酸化水素水 } \\
(30 \%)\end{array}$} & 0.5 & 92.0 & 12.8 & 86.1 \\
\hline & 1.0 & 182.0 & 32.2 & 82.3 \\
\hline \multirow[t]{2}{*}{ ノイゲン HC } & 0.2 & 51.6 & 52.8 & -2.3 \\
\hline & 0.4 & 101.8 & 100.7 & 1.1 \\
\hline ネオレート & 0.2 & 36.8 & 10.0 & 72.8 \\
\hline PLC-2 & 0.4 & 71.2 & 20.5 & 71.2 \\
\hline C.I.Blue & 0.1 & 42.0 & 30.0 & 28.6 \\
\hline 221 & 0.2 & 84.8 & 62.4 & 26.4 \\
\hline C.I.Yellow & 0.1 & 35.2 & 26.2 & 25.6 \\
\hline 145 & 0.2 & 72.0 & 54.4 & 24.4 \\
\hline C.I.Red & 0.1 & 45.2 & 33.0 & 27.0 \\
\hline 223 & 0.2 & 92.8 & 70.0 & 24.6 \\
\hline \multirow[t]{2}{*}{ 酢 酸 } & 0.3 & 22.0 & 22.4 & -1.8 \\
\hline & 0.6 & 45.2 & 44.8 & 1.3 \\
\hline \multirow{2}{*}{$\begin{array}{c}\text { リポオイル } \\
\text { NT-12 }\end{array}$} & 0.5 & 70.6 & 35.4 & 49.9 \\
\hline & 1.0 & 132.0 & 71.8 & 45.6 \\
\hline
\end{tabular}

$\mathrm{pH}: 11, \mathrm{FeSO}_{4} \cdot 7 \mathrm{H}_{2} \mathrm{O}: 1600 \mathrm{mg} / \boldsymbol{\ell}$

の凝集沈殿処理で, 排水成分の分子量による COD 除去率の変動について検討し, 凝集処理では分子量 $10^{4}$ 以下の COD 成分はほとんど除去されないこと を指摘している.このような成分が時間的に負荷変 動して流入する排水は，処理を行っても規制值值を クリアできない可能性がある.一般に, 負荷変動対 策としては，処理装置の容量を十分大きくして，最 大負荷に対しても処理水の水質を保証できるように 保つ方法や処理装置の前に原排水の一時貯留槽を設 けて, 負荷の均一化をはかる方法などの対策がとら れている7). しかし, 本研究結果によると, COD 成 分を効率的に処理するには, 排水成分を十分に把握 し, 化学的処理や生物的処理を受けやすいものなど 区別して，排水成分に合わせた処理を行うことが必 要であるといえる.

な扔, 系染め染色工程は2.1に示したように, 各工 程を経て排水が排出されている.したがって, 精錬, 漂白から染色, オイリングに至るまでのすべての排 水を混合するのでなく, 界面活性剂等の多量に含ま れている精鍊工程からの排水は活性污泥処理を中心 に行い，一方，染色やオイリング剤等は凝集処理へ 送るようにして処理工程の見直しを行うことによ り, 処理効率の向上が図れるものと考えられる.

\section{4.まとめ}

現状の染色排水の処理が行われている処理プロセ
スの凝集沈殿一活性污泥処理工程における処理水の 水質測定を行い, 各工程における処理能力を調べた 結果, 溶解性の COD 濃度を基準にして, 平均して凝 集処理工程で約 $50 \%$ ，そして活性污泥処理工程で残 りの約70\%が除去されていた。こういった処理は, 流入する高負荷排水の時間的な水質変動や水量変動 が問題となる。

また, COD, SS 抢よびろ過液の透視度の処理効率 を調べるため, 非超過確率を調べた結果, それぞれ の水質は, 対数正規分布を示し, また, 年間を通じ た水質変動のバラツキに多少の偏りがあるものの, 排水は効率的に処理されていることがわかった。

凝集沈殿処理工程における処理効率について, 染 色排水の実排水, 模擬排水さらに染色助剂を対象に, 排水成分による COD 濃度の除去率の影響について 検討した結果, 界面活性剂や酢酸などはこの処理工 程ではほとんど処理されておらず，したがって， COD 成分をより効率的に処理するためには, 排水成 分を十分に把握し, 化学的処理や生物的処理など, その成分主体の処理を行うことが必要である.

一方, 最近の着色排水の脱色処理について, 和歌 山市の色規制条例にもあるように, 染色排水の脱色 化が今後主体的な処理になると思われる。たとえば, ろ過排水試料の透視度の測定結果から, 現状の処理 にろ過処理を加えるだけでも放流水の透視度などの 水質は改善されており, 実際の処理工程に適当なろ 過装置を併用すれば，コスト的負担も少ないと推察 される。また，既存法を利用すれば，フェントン酸 化 ${ }^{8)}, 「 \mathrm{PACT}$ プロセス」と呼ばれる粉末状の活性 炭を活性污泥槽に投入する方法 ${ }^{9,10) な と ゙, ~} \mathrm{COD}$ 量の 除去のみならず脱色処理も効果的に行元，有用な方 法の 1 つであると考えられる。

最後に本調查研究につき試料の提供を頂きました 兵庫県繊維染色工業協同組合共同排水処理場長の山 添昌樹氏に心より感謝いたします。

\section{参考文献}

1）三上八州家, 森田博也, 長友二郎, 凝集沈殿法による染色 廃水処理, PPM, 15, 14 (1984).

2) 渡辺孝夫, ビニルスルホン型反応性染料一染色排水の脱色 について, 福島県工試研報, 11, 105 (1980).

3）財兵庫県中小企業振興公社兵庫県産業情報センタ一編, 兵 庫県の地場産業, 地場産業実態調査報告書 (平成10年版), (1997) p.48, 55.

4) 杉本太, 中野恵之, 礒野禎三, 瀬川芳孝, 仙崎俊明, 染色 
加工排水の脱色処理に関する研究, 兵庫工技セ研報, 4, 119 (1994).

5 ) JIS K0102.17 (CODMn).9 (透視度).14.1 (懸濁物質), 工場排水試験方法 (1998).

6 ）美坂康有, 最近の COD 除去プロセス, 第 5 回環境技術シ ンポジウム, 日本能率協会 (1978).

7 ) 久保田宏, 佐野茂俊, 活性污泥法での負荷変動と処理水水 質，水処理技術，19，615（1978）.
8 ) W. G. Kuo, Decolorizing dye wastewater with Fenton's reagent, Water Res., 26, 881 (1992).

9 ) 中野重和, 筧正彦, 粉末活性炭共存活性污泥法による染色 廃水処理，加工技術，28，622（1993）。

10) D. G. Argo, R. L. Culp and S. P. Hansen, Activated Carbon adsorption of organics from the aquous phase vol.2, Ann. Arbor. Sci. (1980), p.349.

\title{
Studies on the Performance and Counterplan of the Treatment of Yarn Dyeing Wastewater
}

\author{
Futoshi SUGIMOTO, Teizo ISONO
}

\begin{abstract}
We studied on the performance of the treatment of yarn dyeing wastewater. The soluble COD was removed in average in an amount of about $50 \%$ in the coagulation-precipitation process, and further removed in an amount of about $70 \%$ of the remaining soluble COD in the activated sludge process.

The monthly data of soluble COD, SS and transparency in raw wastewater and treated wastewater during a year were statistically analyzed in terms of non-exceeding probability, and the result was represented as a logarithmic normal distribution. It was found that the wastewater was efficiently treated with this treatment plant, although the satistical figures showed some scatter.

Moreover, the treatment efficiency of COD in the coagulation-precipitation process was investigated by the synthetic dyeing wastewater. As a result, the surfactant, acetic acid and the like were found to be hardly removed in this process. Therefore, it is made evident that when the wastewater with the components to be hardly removed flows into the treatment plant, it is necessary to perform treatments suitable for wastewater components, including chemical and/or biological treatments.
\end{abstract}

Key Words : dyeing wastewater, coagulation-precipitation process, activated sludge process, synthetic wastewater 